caractères, puisqu'il ne s'agit pas seulement de créer, dans les milieux métropolitains, un courant d'intérêt scientifique vers les problèmes tropicaux, mais de doter les pays d'OutreMer d'une organisation complète entièrement mise à leur service.'

\title{
Blackfriars: Special number
}

Blackfriars, the organ of the English Dominicans at Oxford, devotes its Jan. 1952 number to Africa. This contains a number of articles of unusual interest including a short article by Archbishop Mathew, Apostolic Delegate to British East and West Africa, an account of education in British East Africa by a missionary of the White Fathers, a discussion of some African christian sects, by R. G. Lienhardt and an article on tribal art, by W. Fagg of the British Museum.

Blackfriars is a monthly review and may be ordered from The Manager, Blackfriars Publications, 34 Bloomsbury Street, London, W.C.r.

\section{ETHNOGRAPHIC SURVEY OF AFRICA}

The following sections of the Survey are now available:

The Akan and Ga-Adangme Peoples of the Gold Coast

The Peoples of Sierra Leone Protectorate

The Ibo and Ibibio-speaking Peoples of South-Eastern Nigeria

The Yoruba-speaking Peoples of South-Western Nigeria

Peoples of the Lake Nyasa Region

Bemba and Related Peoples of Northern Rhodesia

The Southern Lunda and Related Peoples

Tribes of the Northern Territories of the Gold Coast

\section{In the Press}

The Coastal Tribes of the North-Eastern Bantu The Nilotic Peoples of the Anglo-Egyptian Sudan

All information about these, and other sections in preparation, may be obtained from the Secretary, International African Institute, who will be pleased to receive standing orders to supply copies of all secrions as they appear. 